\title{
周囲液体からの静液圧と一様な軸圧縮荷重 を受ける円筒款の座屈*
}

一 円筒状海洋構造物の安定性に関する研究（第 3 報）-

土岐 七 $^{1}$ 麻 生 和 $夫^{2}$

\author{
Buckling of Circular Cylindrical Shells Surrounded with Liquid \\ under Axial Compression \\ - Studies on the stability of cylindrical offshore structures (3rd Report) - \\ by Hitoshi DOKI ${ }^{1}$ and Kazuo $\mathrm{ASO}^{2}$ \\ 1. Mining College, Akita University, Akita 010, Associate Professor, Dr. \\ 2. Mining College, Akita University, Akita 010, Professor, Dr.
}

\begin{abstract}
In order to clarify systematically the stability of cylindrical offshore structures, the buckling problem of circular cylindrical shells surrounded with liquid under axial compression is analyzed. A theoretical analysis is performed by means of the Galerkin method on the basis of the Donnell-type equations for shells, taking the effect of the axisymmetric deformation due to the static liquid pressure into consideration. Calculations are carried out for both simply supported and clamped shells and the critical compressive load $k_{c}$ are determined for various values of the shell geometric parameter $Z$, liquid pressure parameter $p_{x}$ and liquid depth ratio $l_{0}$.

The main results obtained are summarized as follows:

(1) The critical compressive load ratio $\bar{k}_{c}$ decreases monotonously with an increase in the value of $l_{0}$ and /or $p_{x}$. With an increase in $l_{0}$, the buckling wave number ratio $\bar{\beta}$ increases for small value of $Z$ and decreases to less than unity for large value of $Z$.

(2) The effects of the shell geometries $Z$ on $\bar{k}_{c}$ are relatively small for clamped shells.

(3) The value of $\bar{k}_{c}$ for simply supported shells is always larger than one for clamped shells in large value of $Z$.

(4) The effects of the surrounding liquid and the axial compression on the prebuckling deformation and the change of buckling mode for the rapid change of buckling load and buckling wave number are clarified by means of the contour map representation.
\end{abstract}

KEY WORDS : Offshore Structure, Stability, Buckling, Cylindrical Shell, Surrounding Liquid, Axial Compression

\section{1. 緒}

円筒状構造物は液体貯槽を初め, 航空機, 化学プラントの配管 等各種産業において広く用いられている基本構造物であり,これ らのうち, 周囲液体からの静液圧を受ける円筒状構造物としては, 半地下構造の石油タンクや高速増殖炉の原子炉容器を初め, 海洋 構造物や土木産業の分野において少なくない。外部からの静液圧 は円筒状構造物を本質的に不安定にするので，各種荷重が複合的 に作用する場合の座屈強度を明らかにすることは, 強度設計上基 本的な重要課題である。

著者らは円筒状海洋構造物の安定性を解明するための第一歩と して，液体に囲まれた円筒殼に各種荷重が作用する場合の座屈現

* 1996 年 7 月 31 日受付 10 月 9 日受理

1. 正会員 工博 秋田大学助教授 鉱山学部機械工学科

2. 正会員 工博 秋田大学教授 鉱山学部機械工学科

〔著者連絡先〕 FAX 0188-37-0405（秋田大・機械）

キーワード: 海洋構造物, 安定性, 座屈, 円筒殼, 周囲液体, 軸圧縮荷重
象を逐次系統的に明らかにすることを目的に，先に周囲液体から の静液圧と一様な外圧を受ける場合 ${ }^{1)}$ ，あるいは一様なねじり荷 重を受ける場合 ${ }^{2)}$ の薄肉円筒殻の座屈強度について理論的な研究 を行った。本論文ではこれらにひき続き, 周囲液体からの静液圧 と一様な軸圧縮荷重を受ける円筒殼の座屈問題を理論的に解析す る。

一般に円筒殻の軸圧縮座屈は, 座屈前の変形性状に敏感であり, 座屈モードも複雑で特異な挙動を示す場合がある。例えば，著者 らの一人が先に行った，液体を部分的に満たした円筒貯槽に各種 荷重が作用する場合の安定性に関する研究3)-8)で明らかにした ように, 外圧座屈やねじり座屈と違い, 軸圧縮座屈荷重は液位の 増加に対して複雑に変動し, 軸圧縮荷重のみが作用したときの座 屈荷重以下になることさえある。したがって本問題を解明するこ とは，液体に囲まれた円筒款が橋桁などとして他の構造物を支え る場合や, 地震の際に半地下構造の石油タンクや円筒状海洋構造 物に軸方向荷重が動的に作用する場合に，その耐荷重能力を算定 し強度設計する上で重要である。境界条件としては, 両端固定お 
よび両端単純支持の 2 つの場合を考え, 座屈前の有限曲げ変形の 影響を考慮に入れた Donnell 型の基礎式に Galerkin 法を適用す ることによって理論的な解析を行う。

\section{2. 基礎式および境界条件}

ここでは円筒状海洋構造物を薄肉円筒殼として解析を行う。図 1 のように半径 $R$, 長さ $L$, 厚さ $h$ の円筒殸の周囲が高さ $H$ まで 密度 $\rho_{f}$ の液体に囲まれており, 款雨端に単位長さ当たり一様分 布軸圧縮荷重 $\sigma_{c} h$ が作用しているものとする。座標軸を図 1 のよ うに定め、円筒殼中央面上の変位成分を $U, V, W$, 合成力に関す る応力関数を $F$ とする。実際の構造物の境界条件を考えた場合, 上端は剛性の高いリングあるいは端板に結合される場合が多く, 一方側板下端は底板に結合され, 更に全体が基礎（海底）上に設 置されたりしているのでかなり複雑であり，明確に指定すること は困難と思われる。そこで本論文では前報1)2)同様、簡単のため 上下両端を同一境界条件とし, 通常座屈問題で考えられている境 界条件のうち, 拘束力が最も強いものと弱いものを考え, 両端固 定で面内変位一定の場合と, 両端単純支持で応力一定の場合を取 り上げ，実際の境界条件はこれらの中間にあるものと考えること にする。

まず座屈前の有限軸対称変形について考える。この場合の変位 を $u_{0}(\xi), v_{0}(\xi), w_{0}(\xi)$, 応力関数を $f_{0}$ とすると基礎式は

$$
\begin{aligned}
& f_{0, \xi \xi \xi \xi}+\alpha w_{0}, \xi \xi \\
& c w_{0}, \xi \xi \xi \xi \\
& -\alpha f_{0}, \xi \xi \\
& -\beta^{2} f_{0}, \eta \eta \\
& w_{0}, \xi \xi
\end{aligned}-\tilde{p} l_{0}\left(1-\frac{\xi}{\pi l_{0}}\right) \varepsilon_{p}=0
$$

$$
u_{0, \xi}+\frac{1}{2} w_{0, \xi^{2}}=\beta^{2} f_{0}, \eta \eta-\nu f_{0}, \xi \xi,-\alpha w_{0}=f_{0}, \xi \xi-\nu \beta^{2} f_{0}, \eta \eta
$$

境界条件は $\xi=0, \pi$ において

$$
\left.\begin{array}{ll}
\text { 両端固定 } \quad: w_{0}=w_{0}, \xi=0 \\
\text { 両端単純支持 } & w_{0}=w_{0}, \xi \xi=0 \\
& \beta^{2} \int_{-\pi}^{\pi} f_{0}, \eta \eta \\
& d \eta=-2 \pi c k_{c}
\end{array}\right\}
$$

座屈の際の基礎式は, 微小増分変位を $u, v, w$, 応力関数を $f$ と すると,

$$
\begin{aligned}
& \nabla^{4} f+\alpha w, \xi \xi+\beta^{2} w_{0}, \xi \xi,_{\eta \eta}=0 \\
& L(w, f) \equiv c \nabla^{4} w-\alpha f_{{ }_{\xi \xi}}-\beta^{2}\left(f_{0},{ }_{\xi \xi} w{ }_{\eta \eta}+f_{0},{ }_{\eta \eta} w,{ }_{\xi \xi}\right. \\
& \left.+f_{{ }_{\eta \eta} \eta} w_{0}, \xi \xi\right)=0 \\
& u,_{\xi}+w_{0, \xi} w,_{\xi}=\beta^{2} f_{, \eta \eta}-\nu f_{,_{\xi \xi}} \\
& \beta v,_{\eta}-\alpha w=f,_{\xi \xi}-\nu \beta^{2} f_{,_{\eta}} \\
& \beta v,_{\eta}+v,_{\xi}+\beta w_{0}, \xi w,_{\eta}=-2(1+\nu) \beta f,{ }_{\xi \eta}
\end{aligned}
$$

境界条件は $\xi=0, \pi$ において

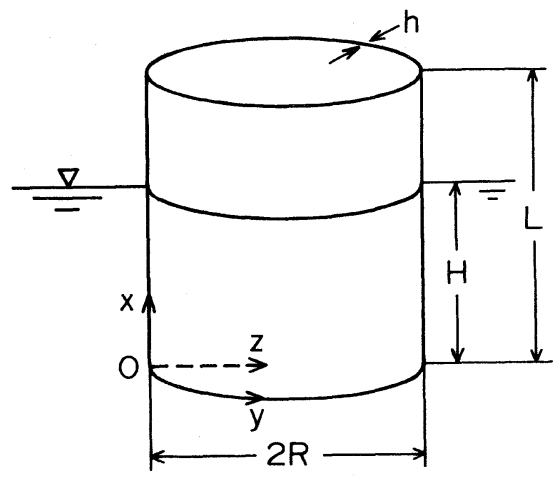

図 1 円筒殼の諸元および座標系
両端固定 $\quad: w=w_{\xi}=u=v=0$ ただし，

$$
\begin{aligned}
& \xi=\frac{\pi x}{L}, \eta=\frac{\pi y}{l}, l=\frac{\pi R}{N}, \beta=\frac{L}{l}, f=\frac{F}{E h^{3}} \\
& (u, v)=\frac{L}{\pi h^{2}}(U, V), w=\frac{W}{h} \\
& \left(n_{x}, n_{y}, n_{x y}\right)=\frac{L^{2}}{\pi^{2} E h^{3}}\left(N_{x}, N_{y}, N_{x y}\right) \\
& c=\frac{1}{12\left(1-\nu^{2}\right)}, \alpha=\frac{L^{2}}{\pi^{2} R h^{3}}, Z=\sqrt{1-\nu^{2}} \frac{L^{2}}{R h} \\
& \tilde{p}=\frac{L^{4}\left(\rho_{f} g L\right)}{\pi^{4} h^{4} E}=K Z k_{p 0} p_{x}, K=\frac{1}{12 \pi^{2}\left(1-\nu^{2}\right)^{3 / 2}} \\
& p_{x}=\frac{\rho_{f} g L}{p_{0}}, k_{p 0}=\frac{p_{0} R L^{2}}{\pi^{2} D}, l_{0}=\frac{H}{L}, k_{c}=\frac{\sigma_{c} h L^{2}}{\pi^{2} D} \\
& D=\frac{E h^{3}}{12\left(1-\nu^{2}\right)}, \varepsilon_{p}=\left\{\begin{array}{l}
1\left(\xi<l_{0} \pi\right) \\
0\left(\xi \geq l_{0} \pi\right)
\end{array}\right.
\end{aligned}
$$

上式においてコンマ後の添字はそれに関する微分を意味し, $N, l$

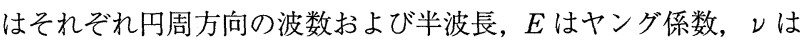
ポアソン比であり， $Z$ (または $\alpha) ， \beta, k_{c}$ はそれぞれ円筒凯の 形状, 波数, 軸圧縮荷重に関する無次元係数である。一般に円筒

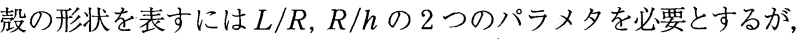
Donnell 型の基礎式を用いた場合，式(9)で定義した円筒凯形状 係数 $Z$ のみで形状を指定することができ， $Z$ が小さい場合は全体 として短い円筒殼を，大きい場合は細長い円筒殼を表す。また， $p_{0}$ は周囲液体がない空の円筒殼に一様外圧のみ作用したときの 座屈圧力であり, $p_{x}$ は本問題において重要な役割を果たす液圧 比で, その物理的な意味は, 密度 $\rho_{f}$ の周囲液体を円筒殼上端ま で満たしたときの底面に扮ける液圧と $p_{0}$ との比である。したがっ て, 周囲液体としては海水のみに限定していないので他の液体の 場合にも適用可能である。

問題は，円筒殼の諸元，材質，液体の種類，液面の高さが与え られた場合に，基礎式(5)，(6)が恒等的に0でない解を持つため の荷重係数 $k_{c}$ の最小値を定めることにある。

\section{3. 座屈前の変形状態}

断面力が軸対称であることと式(1)，(3)，(4)より

$$
f_{0}, \xi \xi=-\alpha w_{0}-\nu c k_{c}, f_{0}, \eta \eta=-\frac{c}{\beta^{2}} k_{c}
$$

したがって座屈前のたわみ $w_{0}$ に関する基礎式は式(2)より

$L_{0}\left(w_{0}, f_{0}\right) \equiv c w_{0}, \xi \xi \xi \xi+c k_{c} w_{0}, \xi \xi+\alpha^{2} w_{0}+c \alpha \nu k_{c}$

$$
-\tilde{p} l_{0}\left(1-\frac{\xi}{\pi l_{0}}\right) \varepsilon_{p}=0
$$

となる。

\section{$3 \cdot 1$ 両端固定の場合}

たわみ $w_{0}$ を式(4)の第一式を考慮して次のように仮定する。

$$
w_{0}=\sum_{m} a_{m}[\cos (m-1) \xi-\cos (m+1) \xi]
$$

ここで $a_{m}(m=1,2,3, \cdots)$ は未定係数である。上式を用い て式(11)に Galerkin 法を適用すると次式を得る。

$$
\begin{aligned}
& \left(2 Z_{0}+Z_{2}\right) a_{1}-Z_{2} a_{3}=-2 \alpha \nu k_{c}-\frac{2}{\pi c}\left\{T_{1}^{(1)}+T_{2}^{(2)}\right\} \\
& Z_{m-1} a_{m-2}-\left(Z_{m-1}+Z_{m+1}\right) a_{m}+Z_{m+1} a_{m+2} \\
& \quad=\frac{2}{\pi c}\left\{T_{1}^{(1)}+T_{2}^{(2)}\right\}, a_{m}=0(m \leq 0),(m \geq 2)
\end{aligned}
$$


ただし，

$$
\begin{aligned}
Z_{m}= & m^{4}-m^{2} k_{c}+\frac{12}{\pi^{4}} Z^{2}, T_{m}^{(1)}=-\tilde{p} l_{0} T_{m} \\
T_{m}^{(2)}= & \frac{\tilde{p}}{\pi}\left[l_{0} \pi T_{m}-\frac{1}{2} l_{0}^{2} \pi^{2} \delta_{m}, 1\right. \\
& +\frac{1-\delta_{m}, 1}{(m-1)^{2}}\left\{\cos (m-1) l_{0} \pi-1\right\} \\
& \left.-\frac{1}{(m+1)^{2}}\left\{\cos (m+1) l_{0} \pi-1\right\}\right] \\
T_{m}= & l_{0} \pi \delta_{m}, 1+\frac{1-\delta_{m}, 1}{m-1} \sin (m-1) l_{0} \pi \\
& -\frac{1}{m+1} \sin (m+1) l_{0} \pi
\end{aligned}
$$

ここで $\delta_{i, j}$ はクロネッカーのデルタである。上式の連立方程式を 解くことにより $a_{m}$ を定めることができる。

\section{$3 \cdot 2$ 両端単純支持の場合}

この場合のたわみ $w_{0}$ を式(4)の第 2 式を考慮して次のように 仮定する。

$$
w_{0}=\sum_{m} a_{m} \sin m \xi
$$

上式を用いて式(11)に Galerkin 法を適用すると，未定係数 $a_{m}$ に関して次式を得る。

$$
a_{m}=\frac{2}{\pi m Z_{m}}\left[-\left\{1-(-1)^{m}\right\} \nu \alpha k_{c}+\frac{\tilde{p}}{c}\left(l_{0}-\frac{1}{\pi m} \sin m l_{0} \pi\right]\right.
$$

\section{4. 座屈条件式}

\section{4 ・1 両端固定の場合}

境界条件を考慮して座屈波形 $w$ を次式で仮定する。

$$
w=\cos \eta \sum_{m} b_{m}\{\cos (m-1) \xi-\cos (m+1) \xi\}
$$

ただし $b_{m}(m=1,2,3, \cdots)$ は未定係数である。式(12)，(17) を式(5)に代入し応力関数 $f$ を求め, ついで基礎式 (6)に Galerkin 法を適用すると次の条件式を得る。

$$
\begin{array}{r}
\int_{-\pi}^{\pi} \int_{0}^{\pi} L(w, f)\{\cos (r-1) \xi-\cos (r+1) \xi\} \cos \eta d \xi d \eta=0, \\
(r=1,2,3, \cdots) \quad \cdots \ldots \ldots \ldots . . . .18)
\end{array}
$$

上式の積分を実行し整理すると, 結局未定係数 $b_{m}$ に関して次式 が得られる。

$$
\begin{array}{r}
\sum_{m}\left\{P_{r m}-k_{c} Q_{r m}+\frac{12 Z^{2}}{\pi^{5}} \beta^{2}\left(R_{r m}+\Phi_{r m}+\Psi_{r m}\right)\right\} b_{m}=0 \\
(m, r=1,2,3, \cdots) \quad \cdots \cdots \cdots \cdots \cdots
\end{array}
$$

ただし

$$
\begin{aligned}
P_{r m}= & \beta^{4} \delta_{r, 1} \delta_{m},{ }_{1}+\left(Z_{r-1}^{\prime}+Z_{r+1}^{\prime}\right) \delta_{r, m} \\
& -Z_{r-1}^{\prime} \delta_{r, m+2}-Z_{r+1}^{\prime} \delta_{r, m-2} \\
Q_{r m}= & \nu \beta^{2} \delta_{r, 1} \delta_{m, 1}+2\left(r^{2}+1+\nu \beta^{2}\right) \delta_{r, m} \\
& -\left\{(r-1)^{2}+\nu \beta^{2}\right\} \delta_{r, m+2}-\left\{(r+1)^{2}+\nu \beta^{2}\right\} \delta_{r, m-2} \\
R_{r m}= & \frac{4 \beta}{(1+\nu) E_{m}^{(1)}}\left\{C+(-1)^{\prime}\right\}\left\{1+(-1)^{r+m}\right\} \\
& \times\left\{g_{r}+(1+\nu) h_{r}\right\}\left\{g_{m}+(1+\nu) h_{m}\right\} \\
\Phi_{r m}= & E_{r m}+F_{r m}+F_{m r}+G_{r m}+G_{m r}, \Psi_{r m}=H_{r m}+I_{r m} \\
E_{r m}= & \frac{\pi}{2 \alpha}\left\{3\left(a_{m-r-1}^{\prime}-a_{m-r+1}^{\prime}-a_{m+r-1}+a_{m+r+1}\right)\right. \\
& +a_{m+r-3}^{\prime}-a_{m-r-3}^{\prime}+a_{m-r+3}^{\prime}-a_{m+r+3} \\
F_{r m}= & \frac{\pi}{2 \alpha}\left\{\gamma_{r-1}+\gamma_{r+1}\right)\left(c_{m-r}-c_{m+r}\right) \\
- & \left.\gamma_{r-1}\left(c_{m-r+2}-c_{m+r-2}\right)\right\}-\gamma_{r+1}\left(c_{m-r-2}-c_{m+r+2}\right)
\end{aligned}
$$

$$
\begin{aligned}
& G_{r m}=\frac{2 \beta}{\alpha(1+\nu) E_{r}^{(1)}}\left\{C+(-1)^{\eta}\right\}\left\{g_{r}+(1+\nu) h_{r}\right\} \\
& \sum_{p=0,1,2, \cdots}\left\{1-(-1)^{p+\eta}\right\}\left(\gamma_{p}-\nu \beta^{2} \lambda_{p}\right) \bar{c}_{p}, m \\
& H_{r m}=\frac{\pi \beta^{2}}{4 \alpha} \sum_{p=0,1,2, \cdots} \lambda_{p} \bar{c}_{p, m}\left(c_{p+r-1}+c_{p-r+1}\right. \\
& \left.-c_{p+r+1}-c_{p-r-1}\right) \\
& I_{r m}=\frac{\beta}{\alpha^{2}(1+\nu)} \sum_{p=0,1,2, \cdots} \\
& \sum_{q=0,1,2, \cdots} \frac{\left\{1+(-1)^{p+q}\right\}\left\{C-(-1)^{p}\right\}}{E_{p}^{(2)}} \\
& \times\left(\gamma_{p}-\nu \beta^{2} \lambda_{p}\right)\left(\gamma_{q}-\nu \beta^{2} \lambda_{q}\right) \bar{c}_{p}, r \bar{c}_{q}, m \\
& Z_{m}^{\prime}=\left(m^{2}+\beta^{2}\right)^{2}+\frac{12 Z^{2}}{\pi^{4}} \frac{m^{4}}{\left(m^{2}+\beta^{2}\right)^{2}} \\
& c_{m}=m^{2}\left(a_{m-1}^{\prime}-a_{m+1}^{\prime}\right), a_{m}^{\prime}=a_{m}-a_{-m} \\
& \bar{c}_{p, m}=c_{p+m-1}+c_{p-m+1}-c_{p+m+1}-c_{p-m-1} \\
& -\delta_{p, 0}\left(c_{m-1}-c_{m+1}\right) \\
& g_{r}=\frac{4 r}{\left\{(r-1)^{2}+\beta^{2}\right\}\left\{(r+1)^{2}+\beta^{2}\right\}} \\
& h_{r}=\frac{4 r\left\{\left(r^{2}-1\right)^{2}-\beta^{4}\right\}}{\left\{(r-1)^{2}+\beta^{2}\right\}^{2}\left\{(r+1)^{2}+\beta^{2}\right\}^{2}}
\end{aligned}
$$

式(19)は $b_{m}$ についての同次の連立一次方程式である。この式が $b_{m}$ に関して恒等的に 0 でない解を持つためには, その係数行列 式 $\Delta$ 茂 とならなければならない。すなわち

$\Delta\left(Z, \nu, \beta, l_{0}, p_{x}, k_{c}\right)=0$

上式より $Z, \nu$ が指定されると, 座屈を起こす $l_{0}, p_{x}, k_{c}$ の組合 せおよびそれに対応する $\beta$ の值, すなわち周囲液体の液位, 液圧 比および軸圧縮座屈荷重とそれに対応する円周方向波数を定める ことができる。

\section{$4 \cdot 2$ 両端単純支持の場合}

この場合の座屈波形を次式で仮定する。

$$
w=\cos \eta \sum_{m} b_{m} \sin m \xi
$$

ただし $b_{m}(m=1,2,3, \cdots)$ は未定係数である。以下両端固 定の場合と同様に Galerkin 法を適用すると最終的に式(19) と同 じ形の式が得られ，座屈条件を定めることができる。

\section{5. 計 算 結 果}

前章までの解析結果に基づき，ポアソン比をン $=0.3 に と り ，$ 円筒款形状係数 $Z$ の種々の值に対して, 座屈を発生する液圧比 $p_{x}$ (周囲液体を円筒款上端まで満たしたときの底面における液圧 と空液時の円筒殼の座屈圧力との比), 液位比 $l_{0}$ (周囲液体の液 位と円筒殼の長さとの比), 軸圧縮座屈荷重係数 $k_{c}$ の組合せ, お よびそれに対応する無次元座屈波数 $\beta$ の值を求めた。なおここで 軸圧縮座屈荷重比 $\bar{k}_{c}$, 座屈波数比 $\bar{\beta}$ を次式で定義する。

$$
\bar{k}_{c}=\frac{k_{c}}{k_{c 0}}, \bar{\beta}=\frac{\beta}{\beta_{c 0}}
$$

上式において， $k_{c 0} ， \beta_{c 0}$ はそれぞれ円筒款外部に周囲液体がな い場合の通常の軸圧縮座屈における座屈荷重係数および波数係数 である。なお, 空液時の円筒殸の座屈圧力と軸圧縮座屈荷重およ びそれらに対応する座屈波数については、種々の境界条件の下に 円筒款形状係数 $Z$ の広い範囲にわたって正確な值が求められて (る ${ }^{9) 10)}$ 。これらのうち本論文の境界条件に対応するものを図 2 に示す。なお, 単純支持の場合の座屈波数は $N=1$ であるので 図示していない。

\section{$5 \cdot 1$ 座屈条件および座屈波数}




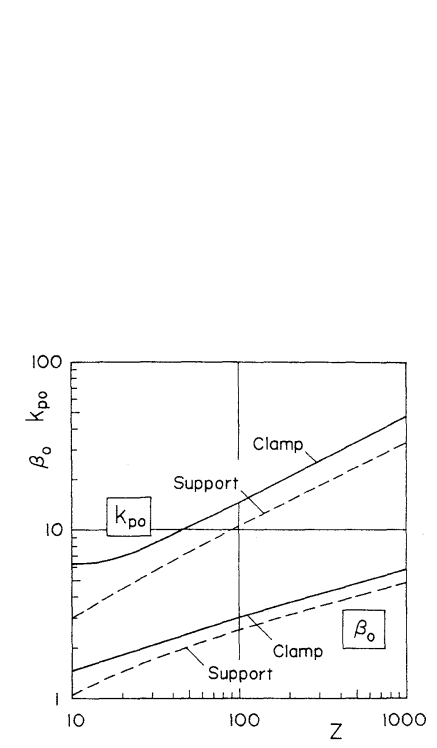

(a) 空液時の円筒殼の座屈圧力 $k_{p 0}$ 㧍よ び座屈波数 $\beta_{0}$

図 2 空液時の円筒款の座屈荷重㧍よび座屈波数

各境界条件の下に, 円筒凯形状係数 $Z$ の種々の值に対し, 液 圧比 $p_{x}$ をパラメ夕にとり, 軸圧縮座屈荷重 $k_{c}$ と刘応する座屈波 数 $\beta$ を液位比 $l_{0}$ に対して算出した。本問の場合一般に円筒殼形 状係数 $Z$, 液位比 $l_{0}$, 液圧比 $p_{x}$ が大なるほど収束が悪くなる傾 向があり, 解の精度は未定係数の数に依存するが, $Z=100$ の場 合 $a_{m}$ を 16 項, $b_{m}$ を 12 項, $Z=1000$ の場合 $a_{m}$ を 32 項, $b_{m}$ を 26 項考慮すれば収束は十分であった。

計算結果を図 3 5 に示す。図 3 は両端固定の場合について $Z$ の種々の值に対して液位比 $l_{0}$ と液圧比 $p_{x}$ を変化させたときの軸 圧縮座屈荷重比 $\bar{k}_{c}$ と座屈波数比 $\bar{\beta}$ を示したものである。いずれ の $Z$ においても, $l_{0}$ の増加に対して $\bar{k}_{c}$ は, はじめはわずかに減 少するだけであるが，ある值を境にして急激に隇少してくること がわかる。また $p_{x}$ が大きいほど $l_{0}$ が小さい值でこの現象が見ら れる。ただし， $Z$ が小さい場合のみ $l_{0}$ が約 $0.2 \sim 0.3$ の範囲では一 時的に $\bar{k}_{c}$ の值がわずかに 1 より大きくなるが, $Z$ が大きい場合 はこの現象は見られない。一方, 座屈波数比 $\bar{\beta} は ~ Z$ が小さい場 合, $l_{0}$ の増加とともに増加し 1 より大きな值を取る。この傾向は $p_{x}$ が大きいほど著しい。しかし $Z$ が大きくなるにつれて全体的 に的は低下し，1 以下の值となる。これは次のような理由による。 一般に, 図 2 から明らかなように, 空液時における座屈波数は $Z$ $=100$ の場合を除いて外圧座屈よりも軸圧縮座屈の方が大きい。 したがって $\beta$ が 1 に近いところでは軸圧縮荷重が周囲液体によ る外圧よりも支配的であり, 逆に 1 より減少するときには周囲液 体による外圧が軸圧縮荷重よりも支配的であることを意味する。 例えば $Z=1000$ の場合, $\bar{k}_{c}$ の曲線が急に折れ曲がっているとこ ろがあるが，これは座屈モードが軸圧縮から外圧に変化している ためで, 対応する $\bar{\beta} も 1$ 付近の值から小さな值に飛び移ってい る。これに関しては座屈波形のところで詳述する。

図 4 は $Z$ の違いによって軸圧縮座屈荷重比 $\bar{k}_{c}$ がどのように変 化するかを, 液圧比が $p_{x}=1.0,3.0,5.0,10.0$ の場合について 示したものである。両端固定の場合, $Z$ の違いによる軸圧縮座屈 荷重比の差は比較的少ないが, 両端単純支持の場合は $l_{0}$ が増加 しても一定 $\left(\bar{k}_{c}=1\right)$ であるが, ある值を境にして急激に減少し, $Z=1000$ の方が軸圧縮座屈荷重比は常に大きいことがわかる。

図 5 は境界条件によって軸圧縮座屈荷重比 $\bar{k}_{c}$ がどのように変
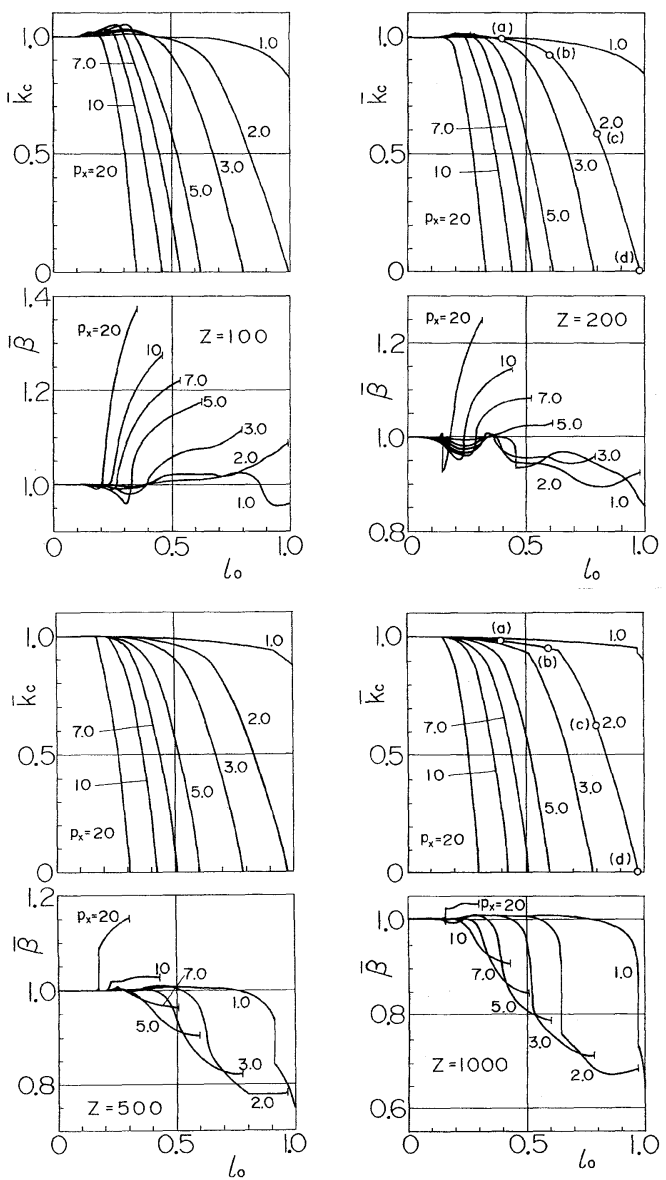

図 3 軸圧縮座屈荷重比 $\bar{k}_{\mathrm{c}}$ および座屈波数比 $\bar{\beta}$ と液位比 $l_{0}$ との関係（両端固定）

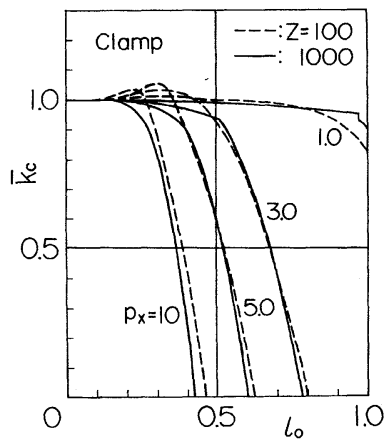

(a) 両端固定

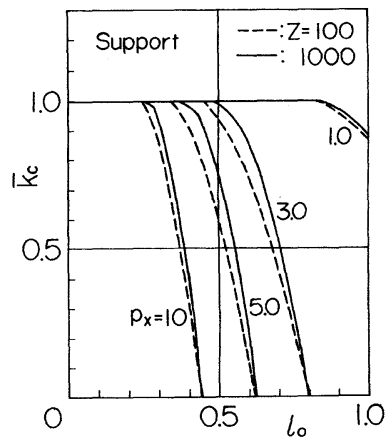

(b) 両端単純支持
図 4 軸圧縮座屈荷重比 $\bar{k}_{\mathrm{c}}$ に及ぼす $Z$ の影響

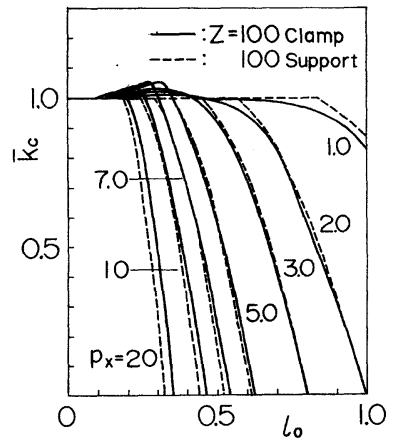

(a) $Z=100$

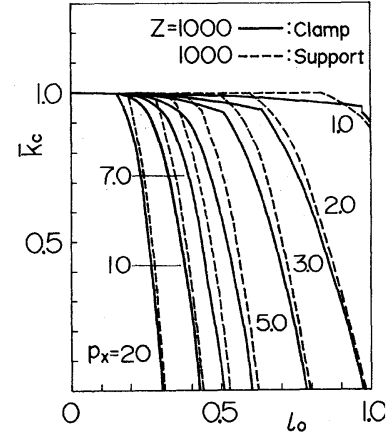

(b) $Z=1000$
図 5 軸圧縮座屈荷重比 $\bar{k}_{\mathrm{c}}$ に及ぼす境界条件の影響 
(a) $\quad l 0=0.40$
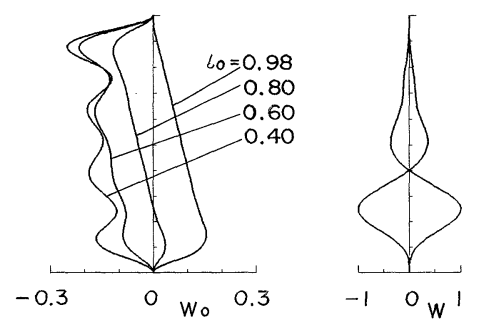

(c)

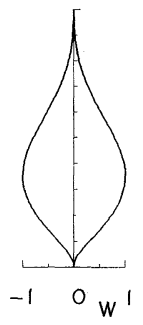

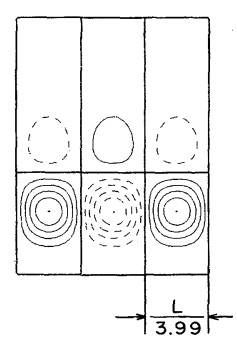

$l_{0}=0.80$

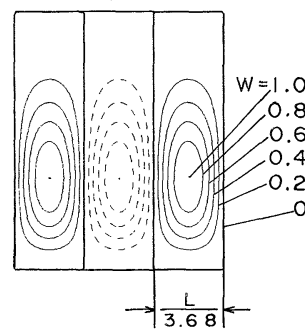

(b) $\quad l_{0}=0.60$
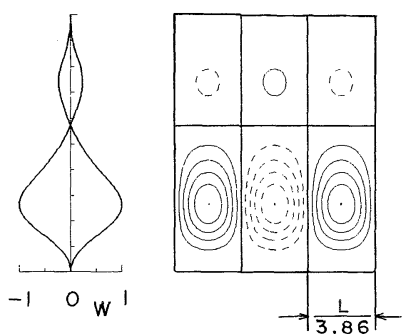

(d)

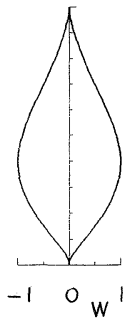

$l_{0}=0.98$

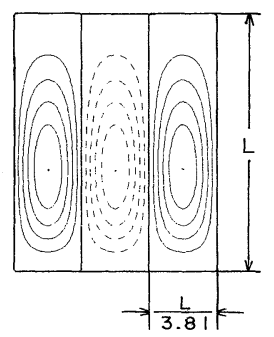

座屈前変形㧍よび座屈波形 (等高線表示) $: Z=200, p_{x}=2.0$, 両端固定

(a) $\quad l_{0}=0.40$
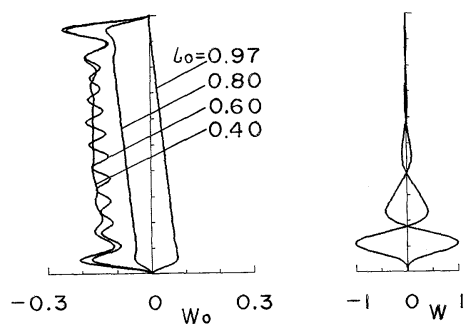

(c)

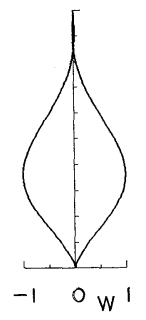

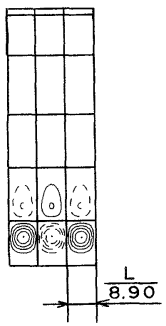

(b) $10=0.60$
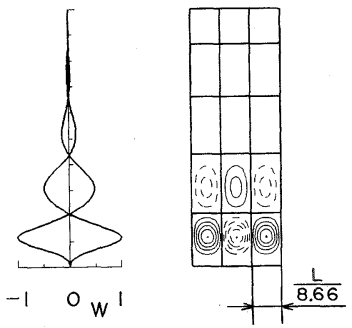

(d) $\quad l_{0}=0.98$

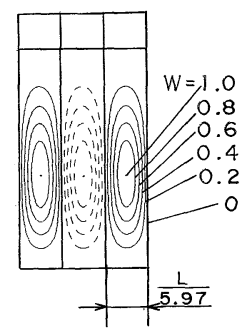

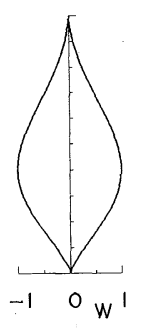

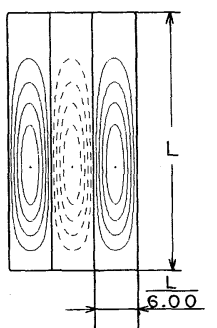

図 7 座屈前変形㧍よび座屈波形 (等高線表示) : $Z=1000, p_{x}=2.0$, 両端固定

化するかを表すために, 代表例として $Z=100,1000$, の場合に ついて示したものである。図より，Zが大きく， $p_{x}$ が小さいほ ど両端単純支持の方が両端固定の場合よりも $\bar{k}_{c}$ の值が大きいこ とがわかる。なお, 図 4,5 は $Z=100,1000$ の場合のみ示して あるが, $Z=200,500$ の場合はこれらの曲線の中間にある。

\section{$5 \cdot 2$ 座屈前変形および座屈波形}

図 6 8 は液位比 $l_{0}$ の変化につれて座屈前の軸対称変形 $w_{0}$ お よび座屈波形 $w$ がどのように変化するかを示すために, 代表例 として両端固定で $Z=200,1000$, 液圧比 $p_{x}=2.0$ の場合および 両端単純支持で $Z=1000, p_{x}=5.0$ の場合について, 座屈前変形 はたわみの軸方向分布を, 座屈波形は 1.5 波長分を等高線表示に より表したものである。なお負の変位に対応する等高線を破線で 示してある。実際には円筒殼は円周方向に円筒面を形成しており,
かつたわみは円周方向に波数 $N$ で周期的に変形しているので, これを平面に展開し, そのうち半波長 3 個相当分のみを取り出し て等高線表示したものである。図中の太線は $w=0$, すなわち たわみが 0 である節線を表している。参考のため $\eta=0, \pi$ にお ける座屈波形の軸方向分布も併せ示した。ここで $w_{0}=1$ は円筒 殸の厚さに相当する変形量を表し, その正負はそれぞれ円筒款の 内および外側への変形を意味する。また座屈の際の増分変位 $w$ の大きさは不定であるので, その最大値を 1 にとり正規化して示 してある。

図 6 は $Z=200, p_{x}=2.0$ (两端固定）の場合の座屈前変形と 座屈波形を示したもので, 図 3 右上 $(Z=200$ の場合) の (a) (d) 点に対応している。座屈前変形 $w_{0}$ の軸方向分布は, 液位比 $l_{0}$ が低いときは上端部から下端部にかけて周期的に外側に張り出す 
(a)
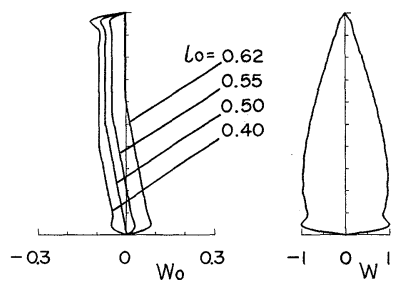

(c)

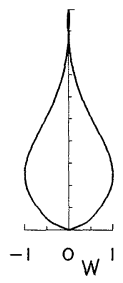

$l_{0}=0.40$

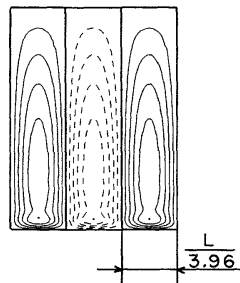

$l_{0}=0.55$

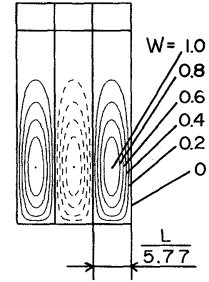

(b)

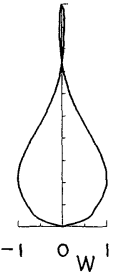

(d)

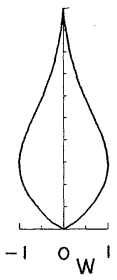

$l_{0}=0.50$

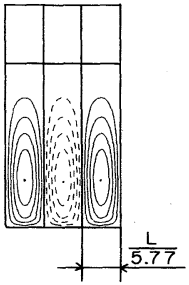

$l_{0}=0.62$

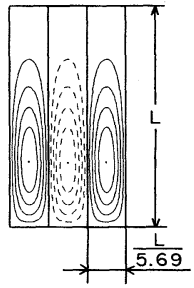

図 8 座屈前变形および座屈波形 (等高線表示) : $Z=1000, p_{x}=5.0$, 両端単純支持

複雑な変形であったものが， $l_{0}$ の増加につれて下端近くで内側に たわみかつ周期的な変形が徐々に取れ，直線的な変形へと移行す

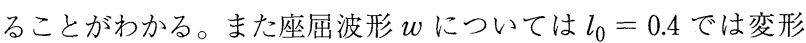
は下半分に集中していたが， $l_{0}$ の増加につれて全体に広がり，最 大たわみ点の位置は上方に移動している。

図 7 は $Z=1000, p_{x}=2.0$ (両端固定) の場合の座屈前変形 と座屈波形を示したもので, 図 3 右下 $(Z=1000$ の場合）の (a) (d) 点に対応している。 $Z=200$ の場合と比較して, 座屈前 変形量は少なくかつ最大たわみ点の位置は下端に非常に近くなっ ていること，また， $l_{0}$ が小さいときに見られた周期的な張り出し の回数はさらに多くなっていることがわかる。一般に， $l_{0}$ が小さ い場合は座屈は主として軸圧縮荷重によって起こり，大きい場合 は周囲液体からの液圧が支配的になる。このため座屈波形は図 $7(\mathrm{a})$ ，(b)では軸方向に関しては高次のモードとなり，最大たわ み点も下端に近くなるのに対し，(c)，(d)では基本的に外圧座屈 である一次のモードになっており, 最大たわみ点も円筒殸中央近 くになっている。また図 3 からこのときの座屈波数比 $\bar{\beta} は(\mathrm{a})$, (b)ではほほ 1 であるのに対し, (a), (d)では 0.7 付近の值に急 滅しており, これに伴い, 円周方向波長が長くなっていることが 大きな特徴である。

図 8 は同じく両端単純支持の場合 $\left(Z=1000, p_{x}=5.0\right)$ につ いて示したものである。境界近傍において固定と単純支持の違い があるほか, 座屈前の変形で見られた周期的な張り出しは見られ ず, 座屈波形は最大でも2 次のモードで, 最大たわみ点の位置が 下端に非常に近くなり，下方が押しつぶされたような波形となる ことがわかる。

\section{6. 結}

円筒状海洋構造物の安定性を系統的に明らかにすることを目的 に, 周囲液体からの静液圧と一様な軸圧縮荷重を受ける円筒殼の 座屈問題を，両端固定および両端単純支持の境界条件の下に，座 屈前の有限曲げ変形の影響を考慮にいれたDonnell 型の基礎式 にGalerkin 法を適用することにより理論的に解析した。種々の 円筒款形状に対し, 周囲液体の液位比 $l_{0}$, 液圧比 $p_{x}$ の值を変化 させて数值計算を行い, 軸圧縮座屈荷重比 $\bar{k}_{c}$ を算出するととも
に, それらと座屈前の有限曲げ変形ならびに座屈波形との関係を も明らかにした。得られた結果を要約すると次のようになる。

(1) 液位比 $l_{0}$ および液圧比 $p_{x}$ が増加するにつれて軸圧縮座 屈荷重比 $\bar{k}_{c}$ は減少する。また, 座屈波数比 $\bar{\beta}$ は液位比 $l_{0}$ が増加 するにつれて，Zが小さい場合は増加するが大きい場合は逆に減 少し, 1 以下の值となる。

（2）両端固定の場合， $Z$ の違いによる軸圧縮座屈荷重比の差 は比較的少ないが，両端単純支持の場合は $Z$ が大きいほど軸圧 縮座屈荷重比は常に大きい。

（3） 円筒殼形状係数 $Z$ が大きく液圧比 $p_{x}$ が小さいほど軸圧 縮座屈荷重比 $\bar{k}_{c}$ は, 両端単純支持の方が両端固定の場合よりも 大きい。

（4）座屈前変形の軸方向分布および座屈波形の等高線表示に より, 座屈荷重と座屈波数の急変に対応する複雑な座屈モードの 変化を明らかにし, 円筒壳の変形に及ぼす周囲液体と軸圧縮荷重 の影響を明らかにした。

終わりにのぞみ，図面作成の一部に秋田大学鉱山学部成田孝二 技官の助力を得た。ここに記して謝意を表する。

\section{引用文献}

1）土岐 仁・麻生和夫·菅 勝重 ·石井憲和 : 資源と素材, Vol. 107, p. 271276, (1991)

2）土岐 仁・麻生和夫 - 菅 勝重 - 石井憲和：資源と素材, Vol. 107, p. 977982, (1991)

3）土岐 化・八巻 昇·谷 順二：日本機械学会論文集 (A 編), Vol. 48, p. 1291-1299, (1982)

4）土岐 仁·八巻 昇·谷 順二：日本機械学会論文集 (A 編), Vol. 48, p. $1300-1309,(1982)$

5）土岐 仁・八巻 昇·谷 順二：日本機械学会論文集 (A 編), Vol. 49, p. 1208-1217, (1983)

6）土岐 仁.八巻 昇·谷 順二. 大友規矩雄 : 日本機械学会論文集 (A 編), Vol. 50, p. 94-102, (1984)

7）土岐 仁.八巻 昇·谷 順二. 大友規矩雄：日本機械学会論文集 (A 編), Vol. 50, p. 936-944, (1984)

8）土岐 仁.八巻 昇 - 谷 順二 · 大友規矩雄 : 東北大学高速力学研究所, Vol . 52 , p. $1-20,(1985)$

9）八巻 昇：東北大学高速力学研究所報告, Vol. 25, p. 153-175, (1970)

10）八巻 昇·児珠昭太郎：東北大学高速力学研究所報告, Vol. 29, p. 133-173, (1971) 